2. To: (Receiving Organization)

Fluor Daniel Hanford SNF

Project Direction

5. Proj./Prog./Dept./Div.:

SNF Project

8. Originator Remarks:

Revised Sampling Campaigns to Provide Sludge for Treatment Process Testing

11. Receiver Remarks: 11A, Design Baseline Document? [] Yes [X] Ho
3. From: (Originating Organization)

Numatec Hanford Corporation SNF Projects

6. Design Authority/ Design Agent/Cog. Engr.:

C.A. Petersen
4. Related EDT Mo.:

N/A

7. Purchase Order Ho.:

N/A

9. Equip./Component Ho.: N/A

10. System/Bldg./Facility: $\mathrm{N} / \mathrm{A}$

12. Major Assm. Dug. Ho.: N/A

13. Permit/Permit Application No.: $N / A$

14. Required Response Date: N/A

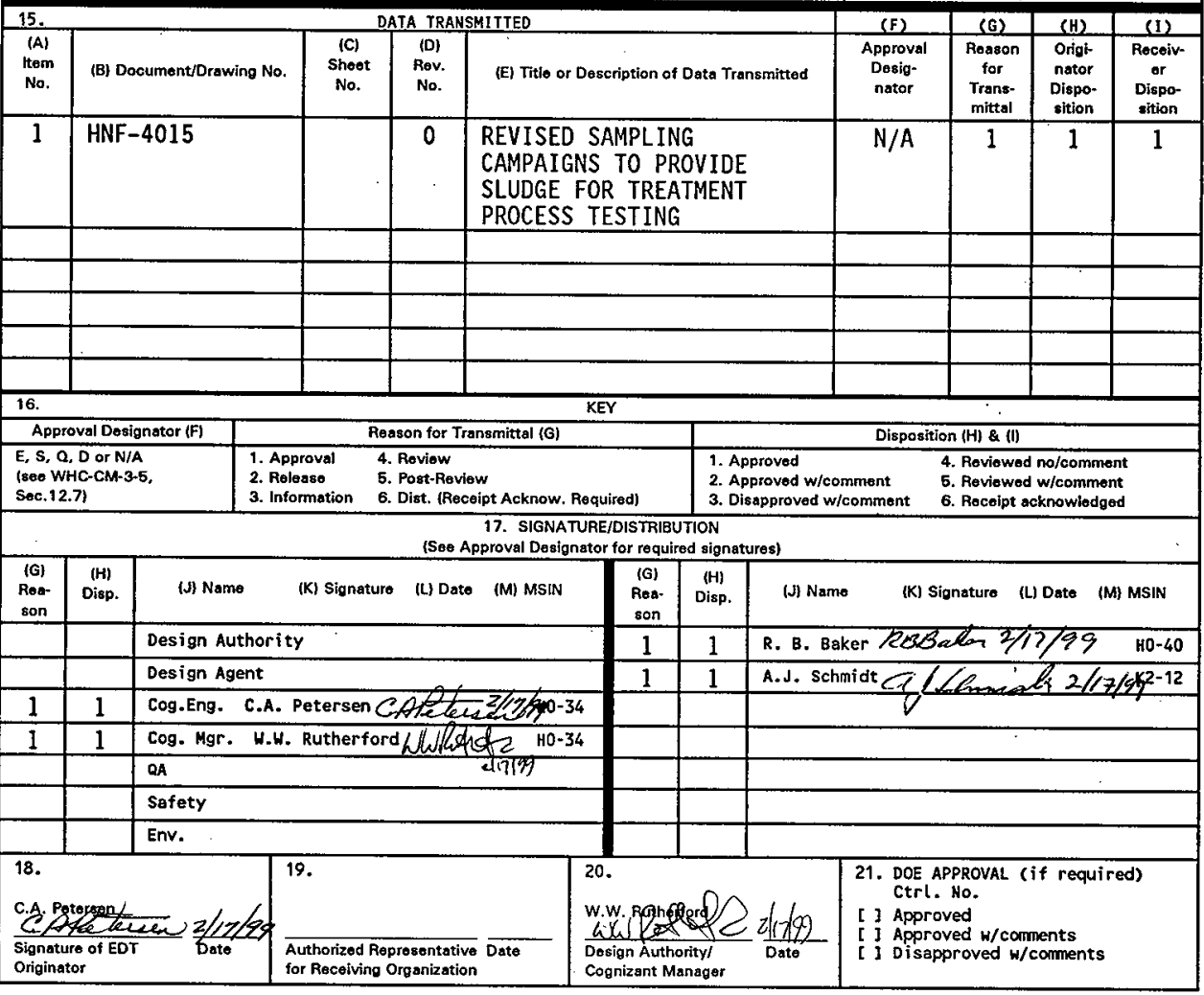




\section{REVISED SAMPLING CAMPAIGNS TO PROVIDE SLUDGE FOR TREATMENT PROCESS TESTING}

\section{A. Petersen}

Numatec Hanford Corporation, Richland, WA 99352

U.S. Department of Energy Contract DE-AC06-96RL13200
EDT/ECN: 620825
UC: UC 2000
Org Code: 82500
B\&R Code: EW7040000
Charge Code: 105359, EH0O/Req 3859 Rel 13 HN960131
Total Pages: 15

Key Words: Sludge Sampling, $K$ Basin Sludge Treatment Process

Abstract: The purpose of this document is to review the impact to the sludge sampling campaigns planned for FY 1999 given the recent decision to delete any further sludge sampling in the K West Basin. Requirements for sludge sample material for sludge treatment process testing are reviewed. Options are discussed for obtaining the volume sample. material required and an optimized $\mathrm{plan}$ for obtaining this sludge is summarized.

TRADEMARK DISCLAIMER. Reference herein to any specific comercial product, process, or service by trade name, trademark, manufacturer, or otherwise, does not necessarily constitute or imply its endorsement, recommendation, or favoring by the United States Government or any agency thereof or its contractors or subcontractors.

Printed in the United States of Anerica. To obtain copies of this document, contact: Document Control Services, P.0. Box 950, Mailstop H6-08, Richland WA 99352, Phone (509) 372-2420;

Fax (509) 376-4989.
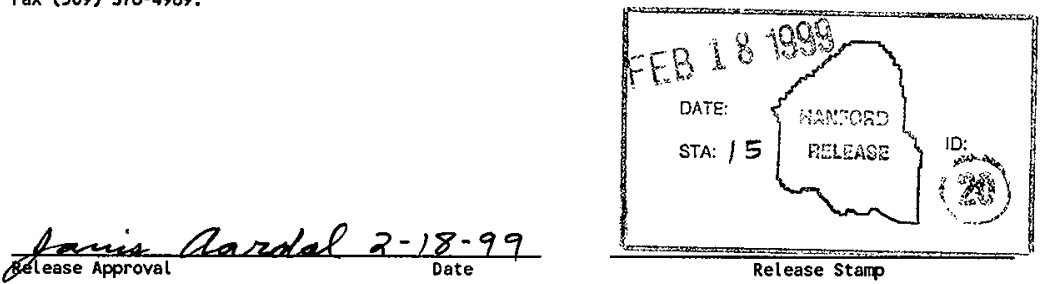
HNF-4015, Rev. 0

\section{REVISED SAMPLING CAMPAIGNS TO PROVIDE SLUDGE} FOR TREATMENT PROCESS TESTING

C. A. Petersen, A. J. Schmidt, and R. B. Baker

February 1999 
HNF-4015, Rev. 0

\section{CONTENTS}

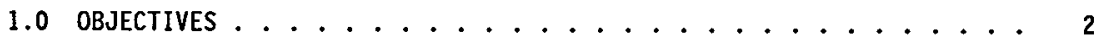

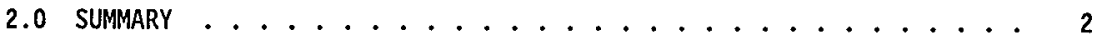

3.0 BACKGROUND ....................... 8

4.0 EVALUATION AND RECOMMENDATIONS ............. 8

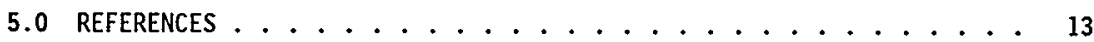

\section{LIST OF TABLES}

1. Projected Quantities Required for Process Testing and Quantities of K East Sludge to be Collected ......... 3

2. Modified Sample Matrix for the Future "Canister" Sampling Campaign ............... 6 
HNF-4015, Rev. 0

\section{REVISED SAMPLING CAMPAIGNS TO PROVIDE SLUDGE \\ FOR TREATMENT PROCESS TESTING}

\subsection{OBJECTIVES}

The primary objectives of the current two sludge sampling campaigns (i.e., on-going floor sludge and planned canister sludge campaigns) are to provide (1) representative sludge materials required for development and validation testing for the Spent Nuclear Fuel (SNF) sludge treatment process, and (2) characterization data on areas with significant sludge inventory that were not previously fully analyzed in prior campaigns. The objective of the present evaluation is to recommend: (1) revised quantities of sludge sample material required from the $K$ East Basin for process testing given the recent decision not to further sample sludge in $K$ West Basin and (2) the most cost effective manner to obtain this required material for process development and validation within the constraints of the two sampling campaigns and the schedule for development of the treatment process.

Specific events and premises driving the recommended revisions of sludge quantities to be obtained from $K$ East Basin are:

1. A recent decision was made by the SNF project to cancel sampling in the $K$ West Basin (Gerber 1999). The prior documented requirements for the sludge treatment process testing included significant quantities of sludge from $K$ West Basin. Acquisition of additional sludge from $K$ East Basin is now needed for process testing to off-set the loss the $K$ West Basin sample material.

2. The two sludge sampling campaigns planned for FY 1999 are scheduled to be the final acquisition of $K$ Basin sludge for treatment process development (i.e., no further sludge acquisitions $\mathrm{planned}$ prior to the start of sludge treatment). Therefore, revisions must address a11 current and future process testing needs.

\subsection{SUMMARY}

Based on this evaluation given the deletion of $K$ West Basin sludge samples, it was concluded additional quantities of $K$ East Basin sludge are required to bring the total amount of sample material back to where there is sufficient sludge for the currently required treatment process testing. Table 1 includes a summary of this evaluation. Column " $A$ " shows the original estimated quantities of sludge needed for process testing including $K$ West Basin sludge (evaluation made in January 1998, Delegard 1998) and Column "B" shows the additional increments now judged as required for updated testing 
HNF-4015, Rev. 0

Table 1. Projected Quantities Required for Process Testing and Quantities of K East Sludge to be Collected (dry sludge basis).

\begin{tabular}{|c|c|c|c|c|c|c|c|c|c|c|c|c|c|c|c|c|c|c|}
\hline \multirow{4}{*}{ 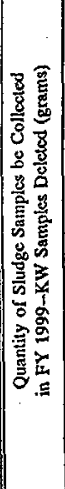 } & \multirow{3}{*}{ 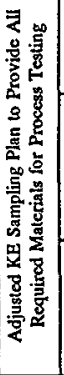 } & 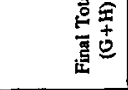 & $\frac{1}{7}$ & 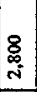 & 悤 & \& & 怘 & 喿 & $\stackrel{\circ}{\circ}$ & స్ & 0 & 0 & 0 & 0 & 10 & 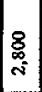 & 若 & 总 \\
\hline & & 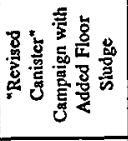 & $\frac{1}{1}$ & 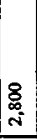 & $\stackrel{\circ}{5}$ & 0 & 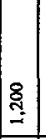 & 0 & 0 & 0 & 0 & 0 & 0 & 0 & 0 & $\begin{array}{l}8 \\
8 \\
-1 \\
-1\end{array}$ & 总 & 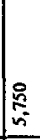 \\
\hline & & 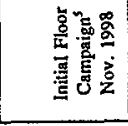 & 竞 & 0 & ב్ & 8 & 8 & 吕 & 怘 & & 0 & 0 & 0 & 0 & 0 & 0 & $\begin{array}{l}\mathscr{Q} \\
: \\
+ \\
+\end{array}$ & 送 \\
\hline & & 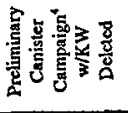 & $\frac{1}{2}$ & 怘 & 10 & 0 & 0 & 10 & 10 & 0 & 0 & 0 & 0 & 0 & 0 & 品 & 0 & 居 \\
\hline 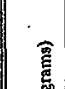 & 웜 & 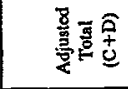 & : & 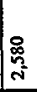 & $\mid \begin{array}{c}8 \\
3 \\
3\end{array}$ & 总 & 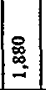 & & $\stackrel{8}{\stackrel{9}{2}}$ & & 0 & & & 0 & & 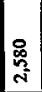 & 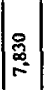 & 送 \\
\hline 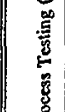 & 吾 & 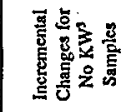 & $\begin{array}{l}1 \\
0 \\
0 \\
2\end{array}$ & 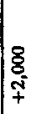 & 兽 & 0 & 0 & & ధి & & 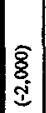 & & & \begin{tabular}{l}
$\overline{8}$ \\
\multirow{2}{*}{} \\
\end{tabular} & & $\stackrel{\theta}{Z}$ & $\begin{array}{l}0 \\
\ddot{z}\end{array}$ & $\stackrel{0}{\vec{t}}$ \\
\hline 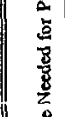 & 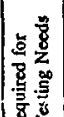 & 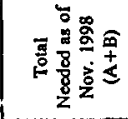 & : & 萿 & 㔛 & 욜 & 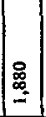 & & $\stackrel{\text { : }}{\stackrel{\text { : }}{-}}$ & & $\begin{array}{l}8 \\
8 \\
\text { i }\end{array}$ & & & 8 & & 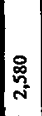 & $\mid \begin{array}{l}8 \\
\infty \\
5 \\
5\end{array}$ & 栗 \\
\hline 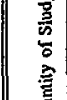 & 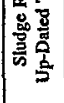 & 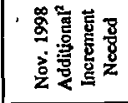 & $\cdot \underbrace{8}$ & 8 & 8 & 8 & 8 & & 0 & & 10 & & & 0 & & 8 & 8 & \&్ \\
\hline 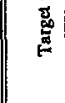 & & 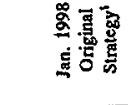 & $\frac{1}{1}$ & 18 & ద్ & 옹 & 总 & & 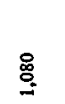 & & \& & & & 点 & & $\begin{array}{c}8 \\
\stackrel{\circ}{\text { i }} \\
\text { i }\end{array}$ & 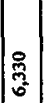 & $\underset{0}{\frac{0}{5}}$ \\
\hline & & 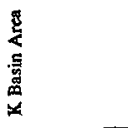 & 题 & 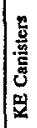 & $\begin{array}{l}\frac{4}{2} \\
\frac{8}{14} \\
3\end{array}$ & 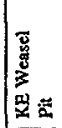 & $\mid \begin{array}{l}z \\
x \\
x \\
z \\
z\end{array}$ & 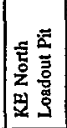 & 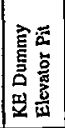 & 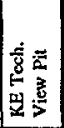 & 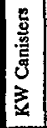 & 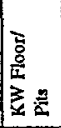 & 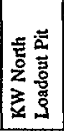 & 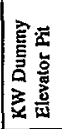 & 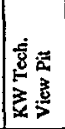 & 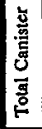 & 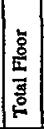 & 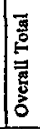 \\
\hline
\end{tabular}


HNF-4015, Rev. 0

Table 1. (Continued)

Notes and Comments:

${ }^{1}$ Estimated quantities of additional sludge from KE Basin required for process development testing--December 1997 estimate (Delegard et al., 1998). Note: these estimated quantities of additional sludge were calculated by subtracting the existing quantities of archived sludge from the total quantities of required sludge for all process development testing.

${ }^{2}$ Based on knowledge of the state of development of the $K$ Basin S1udge Treatment Process as of November 1998, it was determined that an additional $500 \mathrm{~g}$ of sludge should be collected from the KE Floor, KE Floor IXM, KE Weasel Pit, and the KE Canisters. Increased quantities of sludge (i.e., beyond the December 1997 estimates) are projected to be required for: evaluation of alternative sludge treatment technologies; larger scale testing of elutriation and solid/liquid separations; demonstration of sludge transportation within the treatment process; and tank waste compatibility testing (demonstration that treated K Basin sludge is compatible with the waste currently stored in DST AW-105).

${ }^{3}$ On November 9, 1998, a decision was made to cancel a11 KW Basin sludge sample acquisition activities (Gerber 1998). Consequently, additional sludge from $\mathrm{KE}$ Basin will be required to complete testing activities. For example, for canister sludge requirements, $2000 \mathrm{~g}$ has been added to the KE Canister sludge target to compensate for the cancellation of the acquisition of $2000 \mathrm{~g}$ of $\mathrm{KW}$ canister sludge.

"Original campaign planned at beginning of FY 1999 provided five "single pull" samples to obtain a target of $580 \mathrm{~g}$. With this sampling method, the maximum volume in five "single pull" samples would be about 1,400 g.

${ }^{5}$ Baker 1998. 
needs. Column " $C$ " indicates the total updated target quantities, with $K$ West Basin samples still considered. Column "D" indicates quantities of sludge that were to come from $K$ West Basin apportioned to similar areas of $K$ East Basin. Column "E" indicates the final totals required, assuming K East Basin as the only source of test material. The final quantities required for testing are approximately $2,580 \mathrm{~g}$ of sludge from canisters and $7,830 \mathrm{~g}$ from floor and pit areas, for a total of $10,410 \mathrm{~g}$.

Given the target sludge quantities in Column "E" of Table 1, the pending two sludge sampling campaigns were reviewed. If no adjustments were made to the planned sampling campaigns other than deleting the $K$ West Basin samples, the quantity of sludge available for process testing is projected to be $5,150 \mathrm{~g}$ short of the required mass ( $i . e .$, Column "F" only $580 \mathrm{~g}$ from canisters and Column "G" only $4680 \mathrm{~g}$ from the floor and pit areas, for a total of $5,260 \mathrm{~g}$ compared to a required $10,410 \mathrm{~g}$ ). Given this shortage, the most cost efficient and expedient manner to provide the correct quantity of sludge material was evaluated. It was concluded:

1. The present floor sludge campaign will delete the $K$ West Basin sampling as directed, and the $K$ East Basin sampling should be performed as currently specified in the Sampling and Analysis Plan (SAP), Baker 1998. The only modification recommended to this sample acquisition campaign from $K$ East Basin is verification that the projected quantity of sludge from the Weasel Pit is obtained (if quantity of sample material is significantly less than expected one additional sample from the Weasel Pit may be required at the end of this campaign).

2. To obtain the significant required amounts of additional sludge material required for process testing, the "canister" sludge sampling campaign should be modified to (1) use the recently completed higher efficiency "consolidated sampling" equipment and (2) include samples from both the canister barrels and the basin floor, see columns " $H$ " and " $I$ " in Table 1 and the summary in Table 2. As proposed the "canister" sampling campaign (which now would actually include both canister and floor sludge) would still only require one shipment of the Chem-Nuclear cask from $K$ Basins to the 327 Facility, thus resulting in minimal cost impacts. The samples from the "consolidated sampler" would be further validated by crosschecks with samples from the floor and canisters that were drawn with the "single pull" sampling methods.

The estimated net potential cost saving is approximately $\$ 820 \mathrm{~K}$ for simply deleting K West Basin sampling (Columns " $F$ " and " $G$ " of Table 1). The incremental increase in cost to provide the increased amount of sludge material actually required for process testing from $K$ East Basin is approximately an additional \$270K.

Incremental costs for this recommended plan are driven primarily by: (1) sampling activities at the basin such as moving the sampler equipment to multiple locations to obtain the required representative sludge, (2) the 
Table 2. Modified Sample Matrix for the Future "Canister" Sampling Campaign.

\begin{tabular}{|c|c|c|c|}
\hline Sample & $\begin{array}{l}\text { Estimated } \\
\text { Volume of Sludge } \\
\quad(\mathrm{m} \ell)\end{array}$ & $\begin{array}{l}\text { Estimated Weight } \\
\text { of Sludge for } \\
\text { Testing } \\
\text { (g dry) }\end{array}$ & Description \\
\hline 1 & 200 to 400 & 250 & $\begin{array}{l}\text { "Single pull" baseline sample taken from a canister barrel for process testing and } \\
\text { characterization: Use a "single pull" sampler method to draw a "fresh" sample of } \\
\text { sludge from a canister barrel with highly damaged fuel. This sample will have } \\
\text { material with the most representative particle size and condition as no filter is used } \\
\text { and all particles are retained as vacuumed into sample container. }\end{array}$ \\
\hline 2 & 1000 to 2500 & 1275 & $\begin{array}{l}\text { "Consolidated large volume sample" from at least three canister barrels for process } \\
\text { testing: Use the consolidated sampler equipment to draw a "fresh" consolidated } \\
\text { sample from at least three canister barrels each containing highly damaged fuel and } \\
\text { reasonably deep (e.g., greater than } 3 \text { in.) sludge. If possible draw from one canister } \\
\text { barrel in each of the three bays. On a best effort basis, sample will be targeted at } \\
\text { about } 800 \mathrm{~m} \ell \text { from each canister barrel sampled, resulting in a total volume of about } \\
2400 \mathrm{~m} \ell \text { of as-settled sludge. The quantity sampled will be verified in magnitude } \\
\text { with before and after sludge depth measurements in the barrels. All barrels would } \\
\text { likely be fabricated from aluminum. The sample will be checked against Sample } \# 1 \\
\text { (as most representative material) to verify consistency of material. }\end{array}$ \\
\hline 3 & 1000 to 2500 & 1275 & $\begin{array}{l}\text { "Consolidated large volume sample" from at least three barrels of moderately } \\
\text { damaged fuel for process testing: Same as Sample } \# 2 \text { except the samples would be } \\
\text { drawn from at least three barrels each with a moderate level of fuel damage. Samples } \\
\text { may come from barrels fabricated of either aluminum or stainless steel. }\end{array}$ \\
\hline 4 & 700 to 2500 & 875 & $\begin{array}{l}\text { "Consolidated large volume sample" from floor between at least three pairs of slotted } \\
\text { canister barrels for process testing: Use the consolidated sampler equipment to draw } \\
\text { a consolidated sample from floor area between slotted barrels of at least three } \\
\text { canisters, each containing highly damaged fuel and reasonably deep (e.g., greater than } \\
3 \text { in.) sludge. If possible one will be drawn from near a canister in each of the three } \\
\text { bays. On a best effort basis each sample will be targeted at about } 800 \mathrm{~m} \ell \text { each, in a } \\
\text { total volume of about } 2400 \mathrm{~m} \ell \text { of as-settled sludge. A visual perimeter will be used } \\
\text { to estimate the volume in each position. This sample will be validated with Sample } \\
\text { KE-13 from the on-going floor sludge sampling (KE-13 is a single pull sample). }\end{array}$ \\
\hline 5 & 700 to 2500 & 875 & $\begin{array}{l}\text { "Consolidated large volume sample" for process testing taken from at least three deep } \\
\text { sludge areas of the floor in the K East Main Basin: Similar to Sample \#4, only the } \\
\text { sample would be drawn from at least three areas of the main basin where the sludge is } \\
\text { deepest. If possible, one portion would be drawn from each of the three bays. This } \\
\text { sample would exclude IXM bead areas and between barrel areas. It would be } \\
\text { compared to the similar smaller single pull composite sample results from the on- } \\
\text { going floor sludge sampling in K East Basin (KE-1, KE-2, etc.). }\end{array}$ \\
\hline 6 & 1000 to 2500 & 1200 & $\begin{array}{l}\text { "Consolidated large volume sample" for process testing from multiple floor areas in } \\
\text { the K East Basin West Bay where quantities of spilled IXM beads are known to be } \\
\text { present: Multiple locations in cubicles will be sampled in the area near mouth of } \\
\text { North Loadout Pit of the main basin of K East where IXM beads were spilled. The } \\
\text { material will be verified by comparison to the single pull material drawn during the } \\
\text { on-going K East Basin floor sludge campaign (i.e., Samples KE-3 and KE-12). }\end{array}$ \\
\hline
\end{tabular}


handling of one additional sample container, and (3) the laboratories performing an additional suite of initial analyses. The incremental costs are relatively insensitive to the quantity of sludge required (given the magnitude of sludge needed here) because the "consolidated sampling" equipment is able to draw large volume samples of sludge (i.e., up to $3000 \mathrm{ml}$ ), versus the previous "single pull" methods (i.e., only up to $300 \mathrm{ml}$ ); hence costs for $10,400 \mathrm{~g}$ of sludge are roughly the same as for $11,400 \mathrm{~g}$ assuming the same number of basin locations being sampled and same number of sample containers are used to pull them. The new consolidated sampling equipment therefore allows the required quantities to be drawn from the desired range of locations for process testing with minimal additional impact on resources. 
HNF-4015, Rev. 0

\subsection{BACKGROUND}

A sampling campaign is currently underway to provide representative samples of cores of sludge from the floor and pits of the K East Basin, (Baker 1998). A recent review by the SNF Project and Sludge Treatment Process subproject has adopted the position that the cost versus benefit of the sampling of sludges in the $K$ West Basin does not warrant acquiring these samples. This was based on the current chemical treatment process being judged to be robust enough to handle the sludges of the $K$ West Basin and the premise that the behavior of the $K$ East Basin sludges will conservatively bound the behavior of the $K$ West Basin sludges (Petersen 1998; Gerber 1998).

These judgements directly impact the base estimates made previously (Delegard 1998) for the amount and type of sludge samples needed for the process development testing, as the original estimates included significant quantities of sludge from the $K$ West Basin. The original base estimate (Delegard 1998) oniy considered the sludge requirements for the development and demonstration of the chemical processing (acid digest) flow sheet for the K Basin sludge treatment. In September 1998 an effort was initiated to evaluate other potential sludge processing methods. If one or more of these processing alternatives is selected for further development, additional siudge for testing will be required; consequently in November 1998, the target sludge quantities for process testing and validation were increased for a number of sludge types (i.e., see Table 1, Column "B"). It is also noted the current two sludge sampling campaigns are intended to provide all the remaining sludge sample material needed by the SNF project to complete any treatment process testing and development required for the subproject.

None of the base $p$ lanning or related documents up to this point in time (Falment 1998; Delegard 1998; Pearce 1998; Baker 1998) considered using only $K$ East Basin sludge samples (i.e., no $\mathrm{K}$ West samples) to complete process testing for the sludge treatment process. After the current floor sludge sampling campaign (which had $K$ West Sampling as part of its scope) there remains a final sampling campaign originally designated as "canister" sludge sampling. The present evaluation addresses the potential changes to the remaining floor and canister sampling campaigns to obtain the volumes of sludge required for completing the sludge treatment process testing.

\subsection{EVALUATION AND RECOMMENDATIONS}

An evaluation was made of the total quantities of sludge required in the future process testing for $K$ Basins sludge treatment methods and how best to obtain the required sludge material with the remaining sampling campaigns. The present evaluation considered; (1) volumes and types of sludge coming from the on-going sampling of sludges in K East Basin, (2) the el imination of any further sampling of $K$ West Basin sludges, (3) the available sludge material currently archived at the laboratories, (4) testing projections indicated in 
the detailed test strategies (Delegard 1998; Flament 1998) plus the projections to accommodate potential development of a new alternative, (5) available sludge sampling equipment and methods, and the (6) budget, resource and schedule restraints of the SNF Project. Based on the above considerations, the following recommendations are proposed:

1. Use the general overall volumes of sludge projected from the original detailed evaluations for process development and validation testing (Delegard 1998), Column " $A$ " in Table 1. Update these values with the current moderately increased values now judged to be required given present project needs, Column " $B$ " of Table 1, which results in the total target sludge values indicted in Column "C" of Table 1. It was concluded from this evaluation that the quantity of sludge needed for the treatment process testing was not dependent on which basin the sludge sample material came from. Therefore a similar total quantity is still required and the amounts of sludge coming from $K$ West Basin in the original strategy were replaced with sludge sample material from similar areas in $K$ East Basin, as shown in Column "D" of Table 1. The final required total quantities needed from $K$ East Basin sampling are provided in Column " $E$ " of Table 1 (i.e., $2,580 \mathrm{~g}$ from canisters, $7,830 \mathrm{~g}$ from floor and pits, for a total of $10,410 \mathrm{~g}$ ).

2. Given the sludge requirements in Column "E" of Table 1 an evaluation was made of what the result would be if the original sampling campaigns were completed as planned, only $K$ West Basin samples deleted. These results can be seen in Columns " $F$ " and "G" in Table 1 (i.e., $580 \mathrm{~g}$ from canisters, 4,680 g from floor, for a total of only $5,260 \mathrm{mg}$ ). The unadjusted campaigns would result in approximately $5,150 \mathrm{~g}$ less material than required for testing (i.e., the total being short about $50 \%$ of the requirement). Thus, it was concluded an adjustment to the sludge sampling campaigns was needed to provide the required quantities and quality of material, while maintaining as low a cost and schedule impact as possible. Revision of either or both of the pending sludge campaigns was considered. The items that follow in the present text describe the recommended adjusted campaigns.

3. Complete the on-going floor sludge sampling of $K$ East Basin as described in the current Sampling Analysis Plan (Baker 1998) deleting the samples called for from $K$ West Basin. This will produce a set of the required fresh, highly representative sludge material from specified locations in the basin, Column "G" of Table 1. The material in this campaign is composed of samples obtained by isolating cores of sludge with special tubes and then vacuuming using a "single pull" sampler into a set of sample bottles (to obtain the most representative sample possible, all sludge in the core and the water required to lift the sludge sample from the basin floor to the grating is deposited in special bottles on the grating for transport to the laboratories in the PAS-1 casks). 
4. Revise the upcoming "canister sludge" sampling campaign to use the recently completed "consoljdated sampler" equipment to draw a set of large volume samples of sludge from both the floor and the canisters in the $K$ East Basin. This sampling (Column " $H$ " of Table 1) will provide all the remaining required sludge inventory identified as needed for hot process testing. The recently completed "consolidated sampler" equipment maximizes the sampling efficiency by drawing large sludge samples with minimal accompanying water and by representing several basin locations with a single sample container. Since it uses a 5-micron filter to accomplish this, it may loose a small portion of the very fine particles. This potential loss is judged acceptable because: the loses are expected to be smal1, the primary use of the large sample is process testing involving chemistry issues, and closely related but smaller volume, "single pull" sludge samples will be available to verify that these larger samples are representative. Further, cold acceptance tests with this equipment showed that with a simulant potential loss of "fines" is likely to be minimal (Hecht 1999).

The consolidated sampling equipment also allows for moving and collecting sludge from several locations in the basin into a single 10-liter sample container. That is, the sampler "consolidates" material from several locations in one container. The consolidated sampler can pull from $100 \mathrm{~m} \ell$ to over 3000-m\& sludge into one sample container. Thus, for the range of volumes considered here, there is little or no cost impact in increasing sample volume size (i.e., increasing sample size in a sample container from $1500 \mathrm{~m} \ell$ to $2500 \mathrm{~m} \ell$ does not change costs appreciably). Because of their potential high radioactivity levels these 10-1iter sample containers are kept underwater and transported in the Chem-Nuclear cask to the laboratories.

5. Hold costs to minimum by requiring no additional shipments of the Chem-Nuclear cask (i.e., only a single shipment) between $K$ Basins and the 327 Facility. Originally five of the six positions in the single cask were to be used for K East Basin "canister" sampling, with this present proposed adjusted plan all six positions will be used. The recommended sample types are shown in the last three columns of Tables 1 and described in detail in Table 2. Basically this recommended plan uses the consolidated sampler equipment to pull the larger volumes of additional sludge needed for process testing into the six sample containers of the original "canister" sludge campaign. Three of the six containers will address canister sludge material needed; these would be composed of one "single put1" sample (using the consolidated sampler equipment with a check-valve instead of a filter) and two larger consolidated samples. The remaining three samples would address needs for large floor sludge samples. The consolidated floor samples would be validated using the "single pull" samples from the on-going floor sludge campaign. Thus, the two campaigns would be integrated to provide all the 
remaining required sludge sample material currently identified, see Column "I" of Table 1, at as low a cost as possible consistent with good practices. The required total mass of sludge for process testing is about $10,410 \mathrm{~g}$ and the mass of sludge from the sampling is estimated similarly at $10,430 \mathrm{~g}$. [As noted previously an overall cost benefit occurs because this recommended "canister" campaign, while sampling a number of locations in the basin resulting in $5,750 \mathrm{~g}$ of sludge, uses only six sample containers each containing 10-liters of water and sludge; for comparison the "single pul1" sampler used for the initial floor sludge campaign obtains $4,680 \mathrm{~g}$ of sludge in about 38 sample bottles each containing 4-1iters water and sludge.]

6. In the laboratory the recovered material from each of the six sample containers of the "canister" sludge campaign would be subjected to selected analyses so they could be used in the subsequent process treatment testing as soon as possible, in concert with the past archive sludge material and the on-going floor sludge sample material. Since each sample contains specific types of sludge it is recommended analyses would be made of each at this stage, though later samples could be combined. Sludge material with suspected high uranium content would be subjected as quickly as possible to testing sensitive to reactive metal fuel issues. Such testing has not been possible with the aged sludge currently in the 1aboratories.

7. While a potential need for slightly more sludge from the $K$ East Weasel Pit was identified, even after the samples planned for the present floor sludge campaign are taken, it was judged acceptable to consider the amount available sufficient. However, if the current $K$ East Basin Weasel Pit sludge samples (i.e., KE-9 and KE-10) are short on material compared to projections of the SAP, additional sampling with the floor sludge sampler will be required (the consolidated sampler cannot be used in deep sludge in closed off pits such as the Weasel Pit). Therefore, the volume of sludge observed in the primary sample bottles of samples KE-9 and KE-10 should be reviewed as soon as they are in the hot cell to confirm the magnitude of material expected has been obtained.

8. A final minor portion of the sampling plan is the recommendation to lift the canister in cubical 6070 to establish whether it has. screened-bottom barrels. This was the only canister that had a floor sludge sample taken between its barrels during the 1995 sampling of floor sludge in K East Basin. This particular canister had a canister sludge sample taken from one of its barrels in the earlier sampling campaign in 1996. Further, on the floor in this location is also the deepest sludge in the main basin that is not associated with a remote pit mouth. The question remaining at this point in time is "does this canister have screened bottom barrels?". Answering this question will assist in assessing the rest of the basin floor sludge status associated with an "open" or "closed" bottom canister. 
This recommended $\mathrm{plan}$ provides the quantities of sludge needed for required process testing (Column "I" compared to Column "E" in Table 1). Without adjustment for the loss of $K$ West Basin samples, the two sampling campaigns would provide only $5,260 \mathrm{~g}$, short $50 \%$ of the required material. The recommended adjusted $p$ lan is expected to have minimal effect on schedules adding on the order of three weeks overall to the campaign.

There is an estimated approximately $\$ 820 \mathrm{~K}$ cost saving for simply deleting costs of $K$ West Basin sampling (case shown in Columns " $F$ " and "G" of Table 1). The incremental cost to provide the correct amount of sludge material actually required for process testing from $K$ East Basin is an additional \$270K. This incremental increase is small compared to the overall cost of the sampling campaign (in FY 1999 the original campaigns with K West were at about $\$ 2,700 \mathrm{~K}$ ). The cost is also comparatively small versus the value of information resulting from the process development and validation testing associated with this additional quantity of representative sludge material.

Incremental increased costs for this recommended plan are driven primarily by: (1) sampling activities at the basin, such as moving the sampler equipment to multiple locations to obtain the required representative sludge, (2) the handling of one additional sample container, and (3) the laboratories performing an additional suite of initial analyses. Because the consolidated sampling equipment is able to draw large volume samples of sludge (e.g., $3000 \mathrm{~m} \ell$ ) versus previous "single pull" methods (e.g., $300 \mathrm{~m} \ell$ ), the projected incremental cost is relatively insensitive to quantity required given the ranges considered here (e.g., costs for $10,400 \mathrm{~g}$ are roughly the same as for $11,400 \mathrm{~g}$ assuming the same number of basin locations and same number of sample containers). This new consolidated sampling equipment therefore allows the required quantities to be drawn from the desired locations for process testing with minimal additional impact on resources. 


\subsection{REFERENCES}

Baker, R. B., T. L. We1sh, B. J. Makenas, and K. L. Pearce, 1998, Sampling and Analysis Plan for S7udge Located on the Floor and in the Pits of the 105-K Basins, HNF-3556, Rev. 0, Duke Engineering \& Services Hanford, Inc., Richland, Washington.

Baker, R. B., A. L. Pitner, T. L. Welsh, B. J. Makenas, and K. L. Pearce, 1999, Sampling and Analysis Plan for Consolidated Sludge Samples From the Canisters and Floor of the 105-K East Basin, HNF-4016, Rev. 0, Duke Engineering \& Services Hanford, Inc., Richland, Washington.

Delegard, C. H., C. D Carlson, A. J. Schmidt, and K. L. Silvers, 1998, $K$ Basin S7udge Materials Treatment Testing Strategy, HNF-1926, Rev. 0, Duke Engineering \& Services Hanford, Inc., Richland, Washington.

Flament, T. A., 1998, Testing Strategy to Support the Development of K Basin Sludge Treatment Process, HNF-2574, Rev. 0, Duke Engineering \& Services Hanford, Inc., Richland, Washington.

Gerber, E. W., 1998, "Cancellation of K West Basin S7udge Sampling," SNFP Memo 98-SNF/EWG-004 to D. W. Bergmann, dated December 15, 1998, Duke Engineering \& Services Hanford, Inc., Rich1and, Washington.

Hecht, S. L., 1999, System Design Description for the Consolidated S7udge Sampling System for K Basins Floor and Fuel Canisters, HNF-2971, Rev. O, Duke Engineering \& Services Hanford, Inc., Richland, Washington.

Pearce, K. L., 1998, Data Quality Objectives for $K$ Basins Conditioning System Laboratory Testing, HNF-1927, Rev. 0, Duke Engineering \& Services Hanford, Inc., Richland, Washington.

Petersen, C. A., 1998, "Meeting Minutes: K West Basin S7udge Sampling," to Distribution. 


\section{DISTRIBUTION SHEET}

\begin{tabular}{|c|c|c|c|c|c|c|}
\hline \multirow{2}{*}{$\begin{array}{l}\text { To } \\
\text { Distribution }\end{array}$} & \multirow{2}{*}{\multicolumn{3}{|c|}{$\begin{array}{l}\text { From } \\
\text { SNF Sludge Project Definition }\end{array}$}} & \multicolumn{3}{|c|}{ Page 1 of 1} \\
\hline & & & & \multicolumn{3}{|c|}{ Date February 1999} \\
\hline \multicolumn{4}{|c|}{ Project Title $N$ ork Order } & \multicolumn{3}{|c|}{ EDT No. 620825} \\
\hline \multicolumn{4}{|c|}{$\begin{array}{l}\text { Revised Sampling Campaigns to Provide Sludge for Treatment } \\
\text { Process Testing/HNF-4015, Rev. } 0\end{array}$} & \multicolumn{3}{|c|}{ ECN No. } \\
\hline Name & MSIN & $\begin{array}{c}\text { Text } \\
\text { With All } \\
\text { Attach. }\end{array}$ & Text $C$ & & $\begin{array}{c}\text { Attach./ } \\
\text { Appendix } \\
\text { Only }\end{array}$ & $\begin{array}{l}\text { EDT/ECN } \\
\text { Only }\end{array}$ \\
\hline
\end{tabular}

Eluor Daniel Hanford. Inc.

E. W. Gerber

R3-11 X

B\&W Hanford Corporation
A. G. Westra
R3-86
$x$

Duke Engineering \& Services Hanford, Inc.

R. B. Baker (2)

D. W. Bergmann

A. E. Bridges

S. L. Hecht

D. P. Maassen

P. J. MacFarlan

B. J. Makenas

A. L. Pitner

SNF Project File

Lockheed Martin Services, Inc.
HO- 40

HO- 40

HO- 40

HO- 40

HO- 40

$\mathrm{HO}-40$

HO- 40

H0-40

R3-11

B 1-07

$\mathrm{X}$

Numatec Hanford Corporation

D. A. Dodd

T. A. Flament

W. C. Miller

K. L. Pearce

C. A. Petersen (2)

W. W. Rutherford

Pacific Northwest National Laboratory
P. R. Bredt

C. H. Delegard

A. J. Schmidt

K. L. Silvers

DOE/RL Reading Room

$\begin{array}{ll}T 6-50 & X \\ H 0-34 & X \\ H 5-25 & X \\ H 0-34 & X \\ H 0-34 & X \\ H 0-34 & X\end{array}$

$\begin{array}{ll}\text { P7-25 } & \text { X } \\ \text { P7-25 } & \text { X } \\ \text { K2-12 } & \text { X } \\ \text { K9-08 } & \text { X }\end{array}$

H2-53 X 